\title{
Endoparasites Determined by Fecal Examination in Sheep in Erzurum Province
}

\author{
Erzurum İlinde Yetiştirilen Koyunlarda Dışkı Bakısı ile Tespit Edilen \\ Parazitler
}

\author{
(1) Muzaffer Akyüz, (1) Rıdvan Kirman, (1) Sali Yaya, (1) Hatice Gülbeyen, (1) Esin Güven \\ Atatürk University Faculty of Medicine, Department of Parasitology, Erzurum, Turkey
}

Cite this article as: Akyüz M, Kirman R, Yaya S, Gülbeyen H, Güven E. Endoparasites Determined by Fecal Examination in Sheep in Erzurum Province. Turkiye Parazitol Derg 2019;43(4):187-93.

\begin{abstract}
Objective: The aim of the current study was to determine the presence and prevalence of Eimeria and helminth species in sheep raised in Erzurum province by using fecal examination.

Methods: Faecal samples were collected from a total of 784 sheep raised in Aziziye, Yakutiye and Palandöken districts between February-March 2019. The samples were examined by Fulleborn's flotation, Benedect sedimentation, and Baermann-Wetzel methods.

Results: Eimeria spp. and helminths were found in $49.36 \%(387 / 784)$ and $74.11 \%(581 / 784)$ of the samples, respectively. Identified Eimeria species were as follows: E. parva (59.68\%), E. ovina (51.67\%), E. faurei (47.80\%), E. ahsata (39.27\%), E. granulosa (36.62\%), E. punctata (28.42\%), E. pallida (26.09\%), E. ovinoidalis (18.34\%), E. crandallis (16.79\%), E. intricata (15.76\%), E. weybridgensis (11.36\%) and E. marsica (6.20\%). Helminth species identified at genus/species level were Dicrocoelium spp. (33.91\%), Fasciola spp. (5.68\%), Paramphistomum spp. (2.58\%), Moniezia spp. (5.85\%), Trichostrongylid type egg (49.05\%), Marshallagia spp. (38.73\%), Nematodirus spp. (20.98\%), Trichuris spp. (14.46\%), Protostrongylus spp. (18.42\%), Dictyocaulus filaria (2.41\%) and Muellerius capillaris (1.38\%).

Conclusion: Parasitic diseases cause important economic losses in livestock industry. In following years, it is aimed to plan prevention and control strategies for the parasites detected in this area in line with the data of this study and to share this data with the animal breeders.
\end{abstract}

Keywords: Erzurum, sheep, flotation, sedimentation, Baermann-Wetzel

öz

Amaç: Bu çalışmanın amacı, Erzurum ilinde yetiştirilen koyunlarda Eimeria ve helmint türlerinin varlığını ve yaygınlığını dışkı bakısı ile ortaya koymaktır.

Yöntemler: Dışkı örnekleri, Şubat-Mart 2019 tarihlerinde Aziziye, Yakutiye ve Palandöken ilçelerinde yetiştirilen farklı yaş ve cinsiyetteki 784 koyundan toplandı. Toplanan dışkı örnekleri Fulleborn flotasyon, Benedek sedimentasyon ve Baermann-Wetzel metotları ile incelendi.

Bulgular: İncelenen örneklerde, Eimeria oocystleri \%49,36 (387/784), helmint etkenleri ise \%74,11 (581/784) oranlarında saptand. Eimeria spp. pozitif örneklerde; E. parva (\%59,68), E. ovina (\%51,67), E. faurei $(\% 47,80)$, E. ahsata (\%39,27), E. granulosa $(\% 36,62)$, E. punctata $(\% 28,42)$, E. pallida $(\% 26,09)$, E. ovinoidalis $(\% 18,34)$, E. crandallis $(\% 16,79)$, E. intricata $(\% 15,76)$, E. weybridgensis $(\% 11,36)$ ve E. marsica $(\% 6,20)$ türleri belirlendi. Cins/tür bazında tanımlanan helmint etkenleri şunlardır: Dicrocoelium spp. (\%33,91), Fasciola spp. (\%5,68), Paramphistomum spp. (\%2,58), Moniezia spp. (\%5,85), Trichostrongylid tip yumurta (\%49,05), Marshallagia spp. (\%38,73), Nematodirus spp. (\%20,98), Trichuris spp. (\%14,46), Protostrongylus spp. (\%18,42), Dictyocaulus filaria $(\% 2,41)$ ve Muellerius capillaris $(\% 1,38)$.

Sonuç: Paraziter enfeksiyonlar, hayvan yetiştiriciliğinde önemli ekonomik kayıplara neden olmaktadır. İlerleyen dönemlerde, bu çalışmanın verileri doğrultusunda bu bölge hayvanlarında saptanan parazitlere yönelik koruma ve kontrol çalışmalarının planlanması ve hayvan yetiştiricileri ile bu bilgilerin paylaşılması düşünülmektedir.

Anahtar Kelimeler: Erzurum, koyun, flotasyon, sedimentasyon, Baermann-Wetzel

Received/Geliş Tarihi: 16.07.2019 Accepted/Kabul Tarihi: 13.09.2019

Address for Correspondence/Yazar Adresi: Muzaffer Akyüz MD, Atatürk University Faculty of Medicine, Department of Parasitology, Erzurum, Turkey

Phone/Tel: +90 5315152028 E-mail/E-Posta: muzaffer.akyuz@atauni.edu.tr ORCID ID: orcid.org/0000-0002-6095-7870

(c) Copyright 2019 Turkish Society for Parasitology - Available online at www.turkiyeparazitolderg.org

(c) Telif hakkı 2019 Türkiye Parazitoloji Derneği - Makale metnine www.turkiyeparazitolderg.org web sayfasından ulașılabilir. 


\section{INTRODUCTION}

Sheep raising is economically important in the world, as well as in the Erzurum region and Turkey. It is one of the primary sources of animal protein needed for human nutrition. Due to the subtropical climatic conditions of Turkey, inappropriate sheep husbandry systems and parasitic drug resistance, sheep are at high risk to parasitic infections $(1,2)$. Gastrointestinal (GI) parasites are the serious causative species of both clinical and subclinical diseases in sheep which lead to growth retardation, weight loss, mortality, decrease in milk and wool productivity, thus causing tremendous economic losses (2). Therefore, it is very important to investigate the presence and prevalence of disease species, application of appropriate preventive measures and treatment with effective anti-parasitic drugs will aid in the improvement of animal health and economic gain. Based on necropsy and coprological examinations conducted in sheep in different continents and regions of the world, reports showed that the prevalence rate of Eimeria and helminth infections ranges between 4.2-92.9\% (3-7) and $0.2-100 \%(4,8-10)$, respectively. The results of the studies carried out on sheep faecal samples in Turkey, the following 37.3-100\% Eimeria spp. (11-16) and 0.39-100\% helminth (16-18) prevalence were reported. In past years, some studies of sheep parasites presented in Erzurum region (19-21) but contemporarily no comprehensive study has been conducted on endoparasitic fauna of sheep, in Erzurum province. The purpose of this study was to investigate the presence and prevalence of parasitic species at sheep faecal samples by quantitative and qualitative coprological techniques in Erzurum region.

\section{METHODS}

\section{Ethics Committee Approval}

Ethical approval of the study was obtained from the Ethics Committee of Atatürk University of Veterinary Faculty (approval number: 2019/01).

\section{Study Area}

The study was conducted in Erzurum province of Turkey between February-March 2019. The province is the fourth largest city in Turkey with a surface area of $25.066 \mathrm{~km}^{2}$ and located in the northeastern part. It is situated at an elevation of $1853 \mathrm{~m}$ above sea level with an average annual temperature of $5.8^{\circ} \mathrm{C}\left(42.4^{\circ} \mathrm{F}\right)$ and characterized by continental climatic conditions. Erzurum has large expanses of meadows and pastures with a rate of approximately $64.7 \%$. The greenish nature of the meadows and pastures is maintained through all year by sufficient rainfall with average annual precipitation of $425 \mathrm{~mm}$.

\section{Sample Size}

According to the Turkey Statistical Institute (TUIK), Erzurum has the $1.85 \%$ of Turkey's sheep population. The total sheep number in the country is approximately 35.194.972 and 649.716 of them are raised in Erzurum (22). The distribution of sheep breeds in Erzurum is $83 \%, 13 \%, 2 \%$ and $2 \%$ for Morkaraman, Akkaraman, Hemşin, and others, respectively. To determine the sample size, the data of TUIK was considered and 784 (95\% confidence level, $3.5 \%$ confidence interval) sheep found to be enough to represent Erzurum's sheep population. The sample size in terms of the districts was calculated by stratified sampling method.

\section{Sample Collection}

Samples were collected from private sheep farms located in Aziziye, Yakutiye and Palandöken districts between February-March 2019. These districts have similar climatic and geographical conditions. In this study, a total of 784 (females (n): 667, males (n): 117, <1 age group (n): 186, >1 age group (n): 598, race: Morkaraman) clinically healthy sheep faecal samples were collected. The sheep found at meadow or pasture at least once, no administration of antiparasitic drug during the last 3 months and to be raised in Erzurum region were the properties of the sheep that sampled. The faecal samples were collected directly from the rectum of each animal and placed in screw-capped labeled plastic containers. The age, sex, breed, and raising address of the animals were recorded.

\section{Laboratory Techniques}

Collected faecal samples were immediately transported to the Parasitology Laboratory of Veterinary Faculty, Atatürk University. At first, faecal samples were macroscopically investigated in term of consistency, presence of blood, mucus and cestode proglottids. Later on, each of the fecal samples were processed by Fuelleborn's flotation, Benedect sedimentation, Baermann-Wetzel methods and then examined microscopically for the presence of Eimeria spp. oocysts, trematode and cestode eggs, nematode eggs and larvae. Evaluation and identification of the parasitic species at the genus and/or species level were performed by using light microscope (Nikon Eclipse Ci, Japan) and digital camera system (Nikon DS-Fi2, Japan). Quantitative analysis was conducted on all Eimeria positive faecal samples to determine oocysts per gram (OPG) by McMaster's technique (23). The severity of the Eimeria infection was evaluated as mild ( $<1.800$ OPG), moderate (1.8006.000 OPG) and severe (>6000 OPG) (24). Then, $2 \% \mathrm{~K}_{2} \mathrm{Cr}_{2} \mathrm{O}_{7}$ was added to Eimeria positive samples and exposed to sporulation under laboratory conditions by stirring regularly. Identification of sporulated Eimeria oocysts was performed based on morphological features (25). Helminth eggs were defined based on morphological criteria of the eggs at genus/species level, and then eggs per gram (EPG) was calculated in positive samples. Infection degree was evaluated based on EPG as mild (<500), moderate (500-1000) and severe (>1000). Nematode larvae were defined at genus and/or species level according to the morphological criteria (26).

\section{Statistical Analysis}

Positive samples were identified and enumerated. The count data were subjected statistically by SPSS 20 software (SPSS Inc., Chicago, IL, USA), chi-square $\left(\mathrm{x}^{2}\right)$ test to attain associations of sex, age, OPG and EPG at $\mathrm{p}<0.05$.

\section{RESULTS}

The macroscopic examination of the samples revealed that the feces were in normal consistency and not containing blood, mucus, or cestode proglottids. Out of 784 faecal samples, 683 (87.12\%) were found to be positive with at least one parasite. Respectively, 49.36\% (387/784) and 74.11\% (581/784) sheep were infected with Eimeria spp. and helminth species. Whereas 102 (13.01\%) sheep infected with only Eimeria species, 285 (36.35\%) had mix infection with Eimeria species and helminths. Identified Eimeria species were as follows: E. parva, E. ovina, E. faurei, E. ahsata, E. granulosa, E. punctata, E. pallida, E. ovinoidalis, 
E. crandallis, E. intricata, E. weybridgensis and E. marsica (Figure 1). Among the Eimeria species, E. parva has the highest prevalence of $59.68 \%$ (231/387) (Figure 2). In positive samples, 3 to 8 Eimeria species were determined. The infection with 8 Eimeria species were including E. parva, E. ovina, E. faurei, E. granulosa, E. pallida, E. ovinoidalis, E. crandallis and E. marsica.

The prevalence of infection was significantly $(\mathrm{p}<0.05)$ higher in $<1$ age group than $>1$ age group. With regards to sex, the prevalence of infection was higher in females than in males and the difference was insignificant ( $p>0.05)$ (Table 1$)$.

OPG was calculated as $1.550(100-12.850)$ on average. The intensity of infection in age groups ( $<1$ age group: moderate and severe; $>1$ age group: mild) showed statistically significant differences $(\mathrm{p}<0.05)$. The moderate and severe OPG range in females was at high rate while mild OPG range was high in males (p>0.05) (Table 2).

The prevalence rates of helminth infections were as follows; 28.95\% (227/784) trematode, $4.34 \%$ (34/784) cestode, $60.1 \%$ (471/784) GI nematode, and 15.94\% (125/784) lungworm. At least one helminth agent was determined in $74.11 \%(581 / 784)$ of

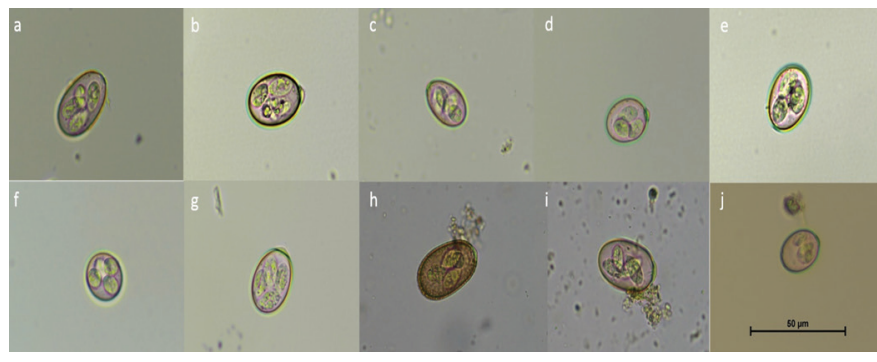

Figure 1. a: E. faurei, b: E. granulosa, c: E. marsica, d: E. ovina, e: E. ovinoidalis, f: E. parva, g: E. weybridgensis, h: E. intricata, i: E. ahsata, j: E. crandallis, Magnification: 400x; Scale bar: $50 \mu \mathrm{m}$

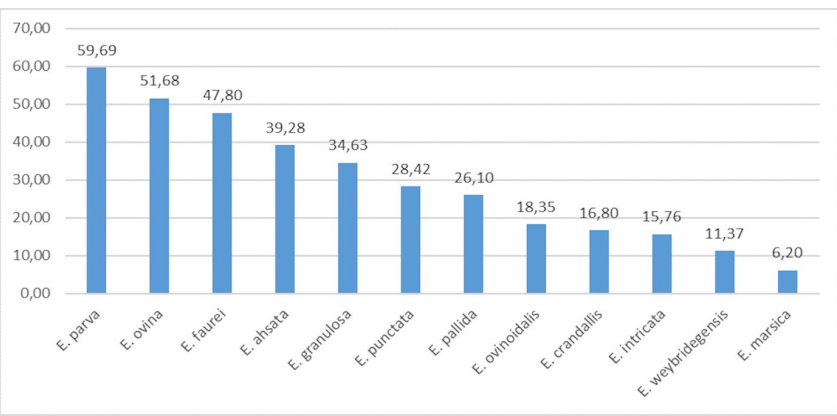

Figure 2. Number of positive animals $(\mathrm{n})=387$ the samples. Identified helminth species at genus or species level were as follows: Dicrocoelium spp. (25.13\%, 197/784), Fasciola spp. (4.21\%, 33/784), Paramphistomum spp. (1.91\%, 15/784), Moniezia spp. (4.34\%, 34/784), trichostrongylid type egg (36.35\%, 285/784), Nematodirus spp. (15.56\%, 122/784), Marshallagia spp. (28.7\%, 225/784), Trichuris spp. (10.71\%, 84/784), Dictyocaulus filaria (D. filaria) (1.79\%, 14/784), Protostrongylus spp. (13.65\%, 107/784) and Muellerius capillaris (M. capillaris) (1.02\%, 88/784). Trichostrongylid type eggs had the highest [49.05\% (285/581)] and $M$. capillaris had the lowest $[1.38 \%(8 / 581)]$ rate in helminth positive samples (Figure 3, 4, 5).

Table 1. Distribution of Eimeria infection in age and sex group

\begin{tabular}{|c|c|c|c|c|}
\hline & & $\mathbf{n} / \mathbf{N}$ & $\%$ & $\mathbf{p}$ \\
\hline \multirow{2}{*}{ Sex } & q & $332 / 667$ & 49.78 & \multirow{2}{*}{$>0.05$} \\
\hline & 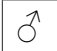 & $55 / 117$ & 47.01 & \\
\hline \multirow{2}{*}{ Age } & $<1$ & $132 / 186$ & 70.97 & \multirow{2}{*}{$<0.05$} \\
\hline & $>1$ & $255 / 598$ & 42.64 & \\
\hline
\end{tabular}

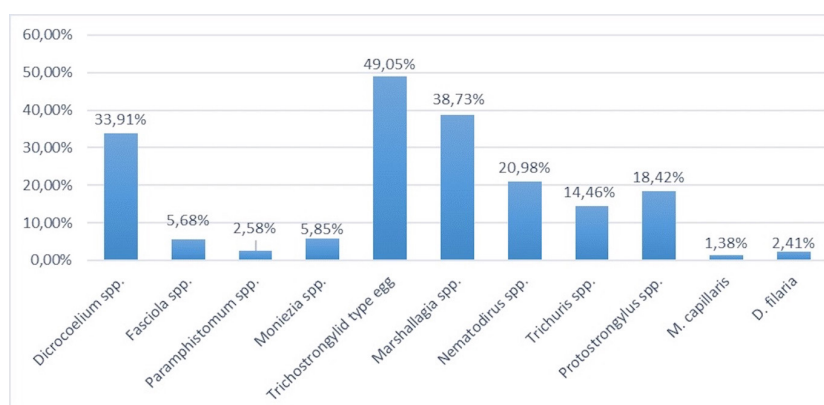

Figure 3. Number of positive animals $(n)=581$

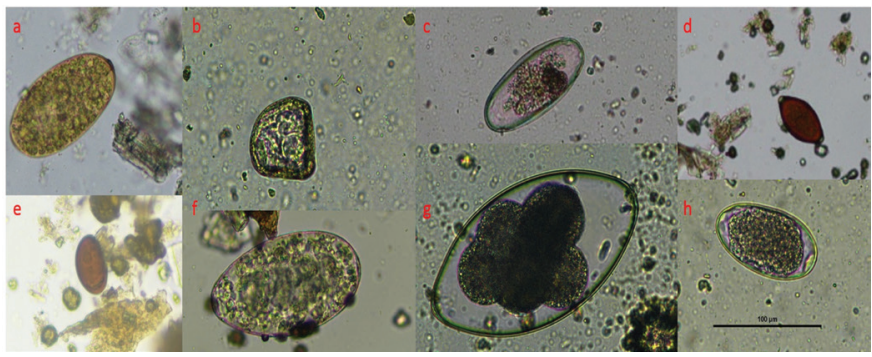

Figure 4. a: Fasciola spp., b: Moniezia spp., c: Marshallagia spp., d: Trichuris spp., e: Dicrocoelium spp., f: Paramphistomum spp., g: Nematodirus spp., h: Trichostrongylid type egg, Magnification: 200x, scale bar: $100 \mu \mathrm{m}$

Table 2. Age and sex-wise OPG range in infective sheep

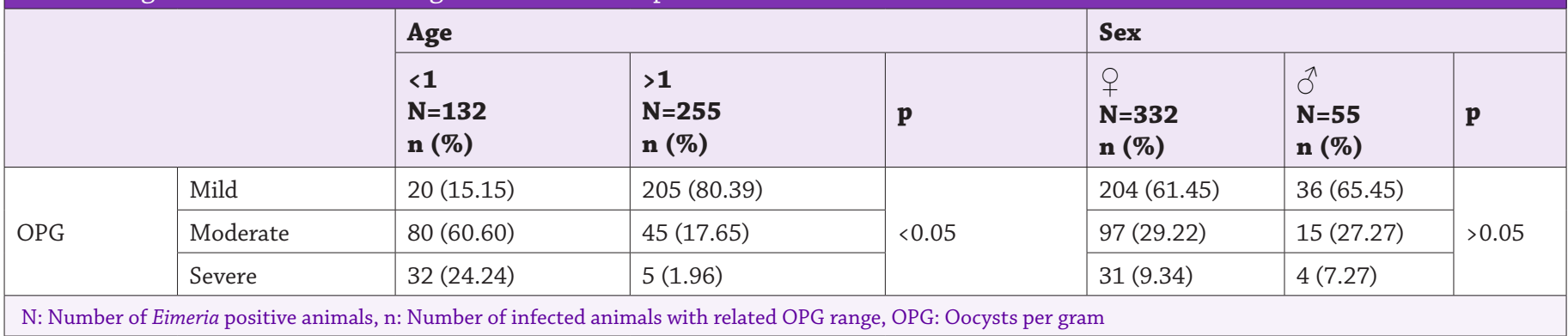


The helminth infection rate was determined higher in the $>1$ age group than $<1$ age group, and the dependency of positivity to the age was found insignificant $(p>0.05)$. The positivity rate was found higher in females than males ( $>0.05$ ) (Table 3).

The presence of Dicrocoelium spp. and Marshallagia spp. was higher in females than males ( $\mathrm{p}<0.05)$ (Table 4).

Single and mix parasite infection rates are shown in Table 5.

EPG was counted as 550 (100-3750) on average. The intensity of infections in age groups ( $<1$ age group: moderate and severe; $>1$ age group: mild) showed statistically significant differences $(p<0.05)$. The severe OPG range was higher in females, while mild and moderate OPG ranges higher in males ( $>$ >0.05) (Table 6).

Table 3. Prevalence of helminth species in the age and sex groups

\begin{tabular}{|c|c|c|c|c|}
\hline & & $\mathbf{n} / \mathbf{N}$ & $\%$ & $\mathbf{p}$ \\
\hline & q & $500 / 667$ & 74.96 & \\
\hline sex & $\sigma^{\pi}$ & $81 / 117$ & 69.23 & $>0.05$ \\
\hline$\hat{1}$ & $<1$ & $133 / 186$ & 71.51 & 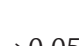 \\
\hline & $>1$ & $448 / 598$ & 74.92 & 30.00 \\
\hline
\end{tabular}

Table 4. Prevalence of helminth species in the age and sex groups

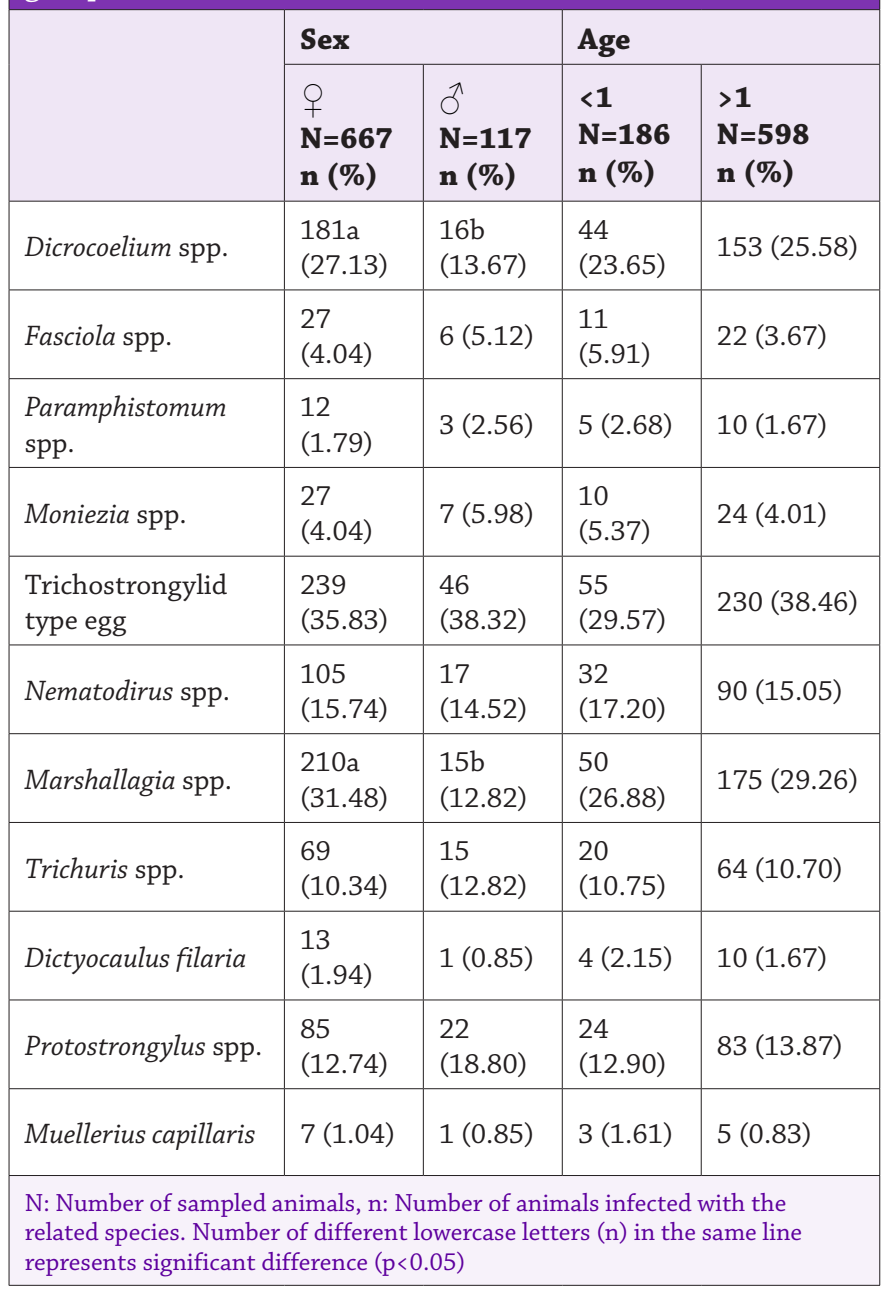

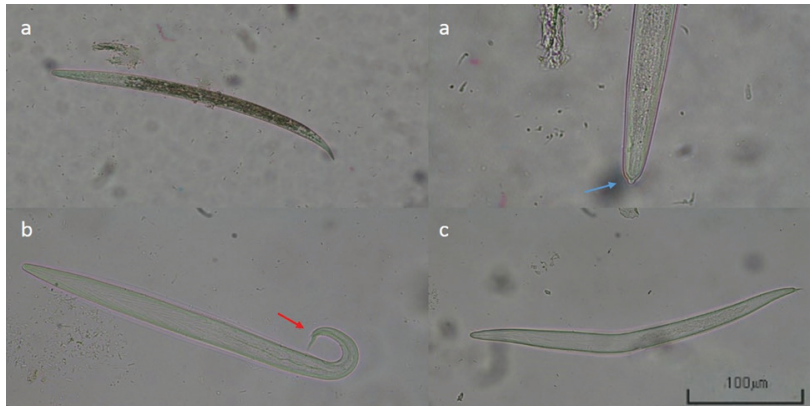

Figure 5. a: D. filaria (blue arrow: protruding knob of the head), b: $M$. capillaris (red arrow: the thorny structure on the tail), c: Protostrongylus spp. Magnification: 100-200x, scale bar: $100 \mu \mathrm{m}$

Table 5. Single and mix infection rates of GI parasites according to the presence of oocytes and eggs in sheep

\begin{tabular}{|c|c|c|c|}
\hline & & $\mathbf{n} / \mathbf{N}$ & $\%$ \\
\hline \multirow{4}{*}{ Single } & Trichostrongylid type egg & 58 & 8.49 \\
\hline & Marshallagia spp. & 63 & 9.22 \\
\hline & Nematodirus spp. & 14 & 2.05 \\
\hline & Trichuris spp. & 11 & 1.61 \\
\hline \multirow{15}{*}{ Double } & $\begin{array}{l}\text { Eimeria spp. + Trichostrongylid } \\
\text { type egg }\end{array}$ & 72 & 10.54 \\
\hline & Eimeria spp. + Marshallagia spp. & 31 & 4.54 \\
\hline & Eimeria spp. + Nematodirus spp. & 7 & 1.02 \\
\hline & Eimeria spp. + Moniezia spp. & 10 & 1.46 \\
\hline & Eimeria spp. + Trichuris spp. & 20 & 2.99 \\
\hline & $\begin{array}{l}\text { Trichostrongylid type egg + } \\
\text { Marshallagia spp. }\end{array}$ & 36 & 5.27 \\
\hline & $\begin{array}{l}\text { Trichostrongylid type egg + } \\
\text { Nematodirus spp. }\end{array}$ & 5 & 0.73 \\
\hline & $\begin{array}{l}\text { Trichostrongylid type egg + } \\
\text { Moniezia spp. }\end{array}$ & 2 & 0.29 \\
\hline & $\begin{array}{l}\text { Trichostrongylid type egg + } \\
\text { Trichuris spp. }\end{array}$ & 9 & 1.32 \\
\hline & $\begin{array}{l}\text { Marshallagia spp. + } \\
\text { Nematodirus spp. }\end{array}$ & 10 & 1.46 \\
\hline & $\begin{array}{l}\text { Marshallagia spp. + Moniezia } \\
\text { spp. }\end{array}$ & 1 & 0.15 \\
\hline & $\begin{array}{l}\text { Marshallagia spp. + Trichuris } \\
\text { spp. }\end{array}$ & 3 & 0.44 \\
\hline & Moniezia spp. + Trichuris spp. & 1 & 0.15 \\
\hline & $\begin{array}{l}\text { Nematodirus spp. + Moniezia } \\
\text { spp. }\end{array}$ & 1 & 0.15 \\
\hline & $\begin{array}{l}\text { Nematodirus spp. + Trichuris } \\
\text { spp. }\end{array}$ & 1 & 0.15 \\
\hline \multirow{2}{*}{ Triple } & Eimeria spp. + 2 GI helmint & 69 & 10.10 \\
\hline & GI helmint & 22 & 3.22 \\
\hline \multirow{3}{*}{$>$ Triple } & Eimeria spp. + 3 GI helmint & 24 & 3.51 \\
\hline & Eimeria spp. +4 GI helmint & 7 & 1.02 \\
\hline & GI helmint & 4 & 0.59 \\
\hline
\end{tabular}


Table 6. Age and sex-wise EPG range in infective sheep

\begin{tabular}{|c|c|c|c|c|c|c|c|}
\hline & \multicolumn{3}{|l|}{ Age } & \multicolumn{3}{|l|}{ Sex } \\
\hline & & $\begin{array}{l}<1 \\
\mathrm{~N}=98 \\
\mathrm{n}(\%)\end{array}$ & $\begin{array}{l}>1 \\
\mathrm{~N}=373 \\
\mathrm{n}(\%)\end{array}$ & $\mathbf{p}$ & $\begin{array}{l}q \\
\text { N=407 } \\
\text { n (\%) }\end{array}$ & $\begin{array}{l}\text { ઊી } \\
\mathrm{N}=\mathbf{6 4} \\
\mathrm{n}(\mathbf{\%})\end{array}$ & $\mathbf{p}$ \\
\hline \multirow{3}{*}{ EPG } & Mild & $16(16.33)$ & 251 (67.29) & \multirow{3}{*}{$<0.05$} & 27 (55.77) & $40(62.50)$ & \multirow{3}{*}{$>0.05$} \\
\hline & Moderate & 67 (68.37) & $114(30.56)$ & & $160(31.31)$ & 21 (32.81) & \\
\hline & Severe & $15(15.31)$ & $8(2.14)$ & & $20(4.91)$ & $3(4.69)$ & \\
\hline
\end{tabular}

N: Number of GIN infected animals, n: Number of infected animals with related EPG range, EPG: Eggs per gram

\section{DISCUSSION}

The presence and prevalence of Eimeria and helminth species in sheep were revealed by qualitative and quantitative coprological techniques and it was observed that $87.12 \%$ of the sampled sheep was infected with at least one parasitic agent.

The prevalence of Eimeria infection, a common problem in all sheep breeding countries worldwide, is reported between 11.4$92.9 \%$ (3-7) in the world and $37.3-100 \%$ (11-16) in Turkey. In the previous studies conducted in sheep in different provinces of Turkey, the prevalence of Eimeria species was between $56 \%$ and $100 \%(12,13,15,16)$. The prevalence was $49.36 \%$ in this study which is lower than the mentioned studies. In contrast, Sayın et al. (11), reported a lower prevalence (37.26\%) in their study including sheep samples from different cities in the Aegean region. Eimeria species have high morbidity as a result of high flock population, poor sanitation, irregular litter removal, immunosuppression connected with stress factors and concurrent infections $(2,6)$.

The differences in the prevalence of Eimeria infections in regions or provinces are related to the variation in climate, husbandry and nutrition, sheepfold conditions, anticoccidial drug usage, breed, age, health and immunity status of the sheep and diagnostic methods used for the analysis.

Currently, fifteen Eimeria species are known to infect sheep (25). In Turkey, twelve Eimeria species have been identified so far $(13,15)$ and all those species were observed in the present study. Immunity is one of the most important factors affecting the presence and prevalence of Eimeria infections. The host's immunity can change depending on the age and sex of the animal. In the earlier studies, findings of more prevalent Eimeria infections in females than males caused by some stress-factors such as pregnancy, lambing, and lactation were reported $(6,27)$. In the present study, compatible results with those studies were obtained. Specific immunity develops against recurrent Eimeria infections with the advance in age of the animals. The Eimeria spp. infections were found higher in $<1$ age group than $>1$ age group at the present study, and this result is similar with the previous studies $(6,28)$. The OPG ranges, moderate and severe in $<1$ age group while mild in $>1$ age group were determined. Similar result was reported by other researchers $(5,27,28)$. In the earlier ages of the sheep when the immune system is not developed accurately, the oocyst output rates are at high levels for Eimeria infections. The oocyst output rates decrease with the advancing ages and reinfections. Moderate and severe OPG in females, and mild OPG in males were determined in this study. Similar result was reported by Khan et al. (27) and Yakhchali and Golami (29). High levels of OPG in females is clarified by high number of oocyst production as a result of immune depression due to physiological stress factors such as pregnancy, lambing, and lactation (6).

The prevalence of helminths in sheep was reported between 0.2$100 \%$ around the world in the studies based on necropsy and stool examination (4,8-10). The prevalence of trematodes, cestodes, GINs, and lung nematodes were reported between $3.1-72.6 \%$ $(30,31), 7.56-21 \%(16,32), 0.39-100 \%(16-18)$ and $7.8-34 \%$ $(16,33)$, respectively, in Turkey. In this study, the prevalence of trematodes, cestodes, GINs, and lung nematodes were determined as $28.95 \%, 4.34 \%, 60.10 \%$, and $15.94 \%$, respectively. The present results were lower than the results of earlier studies of India $(34,35) 77.75-90.11 \%$; Turkey $(16,17) 75-100 \%$ and Spain (8) $100 \%$. Distinctly, lower rates than this study were stated in India (68.55\%), Ethiopia (63.33\%) and Germany (62.8\%) $(9,24,36)$. The differences in the prevalence of helminth infections depend on many factors including the parasite (biological features), host (genetic resistance, age, physiological status) and environmental factors (climate, elevation, husbandry system). The pasture composition, animal diversity and the rate of herds and flocks in the same pasture are very important in the transmission of helminths due to the contamination of the pasture $(9,37,38)$. In addition, antiparasitic drug usage, sample size, and co-infections have effect on the prevalence of the parasitic infections $(9,34)$.

Trichostrongylid type eggs were found at the highest rate (49.5\%) among the helminth positive samples which can be explained by the direct life cycle of these species. These results are supported by the studies of some researchers $(9,10,16,37)$. The helminth infections were more prevalent in females (74.96\%) than males (69.23\%) in this study. Similar results were reported by Khajuria et al. (36) and Belina et al. (9). In contrast, Idris et al. (24), and Yasmin et al. (39), stated that helminth infections were more prevalent in males $(24,39)$. Similar to the Eimeria infection, physiological stress factors which cause immunodepression are responsible for the high prevalence of helminth infections in females (35). Age is another factor that affects the prevalence of GI parasites. In general, adults are more resistant to the parasitic infections than younger animals due to age-related changes in the host immunity. In this study, higher infection rate was observed in adults which was in line with the results of Belina et al., (2017) and Singh (2017) (9,34). On the contrary, Idris et al., (2012) and Khajuria et al., (2013) presented higher infection rate in young animals $(24,36)$. The reasons of higher infection rate in adults can be explained by the spread on large areas during grazing, overfeeding on contaminated pastures and more exposure to stress factors. The EPG ranges were determined as severe in the 
$<1$ age group and females, mild and moderate infection in the $>1$ age group and males. The variety among the age groups can be commented with the immunity resulting from recurrent infection in the meantime the variety in the sex groups can be explained by the physiological status effect similar to the OPG ranges. The EPG range was determined higher in young animals by Idris et al., (2012), and in females by Khajuria et al., (2013) similar to the present study. But, on the other hand, some studies presented higher EPG range in males $(24,36)$.

\section{CONCLUSION}

This study reports the presence and prevalence of Eimeria spp, GI system helminths and lung nematodes in sheep flocks in Erzurum province of Turkey. Considering the high prevalence of these parasites in study area, it is concluded that effective control and management programs should be applied including proper usage of anthelmintics and anticoccidials to improve the health and productivity of the animals.

\section{* Ethics}

Ethics Committee Approval: Ethical approval of the study was obtained from the Ethics Committee of Atatürk University of Veterinary Faculty (approval number: 2019/01).

Informed Consent: Informed consent is not necessary as it is an animal experiment.

Peer-review: Internally peer-reviewed.

\section{* Authorship Contributions}

Concept: E.G., M.A., R.K., S.Y., H.G., Design: E.G., M.A., R.K., S.Y., H.G., Data Collection or Processing: E.G., M.A., R.K., S.Y., H.G., Analysis or Interpretation: M.A., Literature Search: M.A., Writing: M.A., E.G.

Conflict of Interest: No conflict of interest was declared by the authors.

Financial Disclosure: The authors declared that this study received no financial support.

\section{REFERENCES}

1. Bölükbaş C S, Doğanay A. Helmint enfeksiyonların da alternatif kontrol yaklaşımları. Turkiye Parazitol Derg 2007;31:322-6.

2. Taylor M A. Emerging parasitic diseases of sheep. Vet Parasitol 2012;189:2-7.

3. Wang C R, Xiao J Y, Chen A H, Chen J, Wang Y, Gao Y F, et al. Prevalence of coccidial infection in sheep and goats in northeastern China. Vet Parasitol 2010;174:213-7.

4. Katharina R, Lea H, Claudia B, Sonja W, Christian E, Christina S. 10-year parasitological examination results (2003 to 2012) of faecal samples from horses, ruminants, pigs, dogs, cats, rabbits and hedgehogs. Parasitol Res 2017;116:3315-30

5. Carrau T, Silva L M R, Pérez D, Failing K, Martínez-Carrasco C, Macías $\mathrm{J}$, et al. Associated risk factors influencing ovine Eimeria infections in southern Spain. Vet Parasitol 2018;263:54-8.

6. Mohamaden W I, Sallam N H, Abouelhassan E M. Prevalence of Eimeria species among sheep and goats in Suez Governorate, Egypt. J Vet Med Sci 2018;6:65-72.

7. Oliveira de Macedoa L, Santosa M A B, Marinho da Silvaa N M, Maciel do Rêgo Barrosa G M, Alvesb L C, Giannellic A, et al. Morphological and epidemiological data on Eimeria species infecting small ruminants in Brazil. Small Rum. Res 2019;171:37-41.
8. Pedreira J, Paz-Silva A, Sanchez-Andrade R, Suarez J L, Arias M, Lomba $C$, et al. Prevalences of gastrointestinal parasites in sheep and parasitecontrol practices in NW Spain. Prev Vet Med 2006;75:56-62.

9. Belina D, Giri A, Mengistu S, Eshetu A. Gastrointestinal Nematodes in Ruminants: The Parasite Burden, Associated Risk Factors and Anthelmintic Utilization Practices in Selected Districts of East and Western Hararghe, Ethiopia. J Vet Sci 2017;8:2-7.

10. Brahma A, Jas R, Das S, Ghosh J. Prevalence of Gastrointestinal Helminth Infection in Garole Sheep of Sundarban Delta in West Bengal. Indian J Anim Res 2018;8:57-60.

11. Sayın F, Kahyaoğlu T, Çakmak A. Ege Bölgesinde (İzmir, Manisa, Aydın) koyun ve keçilerde Eimeria türlerinin tespiti. Ankara Üniv Vet Fak Derg 1986;33:90-6.

12. Demir S. Eimeria species in sheep slaughtered in Bursa meat and fish plant. Acta Parasitol 1995;19:132-9.

13. Arslan M O, Umur S, Kara M. The prevalence of Coccidian Species in Sheep in Kars Province of Turkey. Trop Anim Health Prod 1999;31:161-5.

14. Özer E, Şaki C E. Türkiye'de coccidiosis. In: Coccidiosis. Dincer S, Editör. Turkiye Parazitol Derg İzmir; 2001. p. 151-162.

15. Kaya G. Prevalence of Eimeria Species in Lambs in Antakya Province. Turk J Vet Anim Sci 2004;28:687-92.

16. Gül A, Kılınç S G. Bingöl Belediye Mezbahasında Kesimi Yapılan Koyun ve Keçilerde Dışkı Bakılarına Göre Endoparaziterin Yaygınlı̆ının Araștırılması. Dicle Üniv Vet Fak Derg 2016;2:61-6.

17. Umur S, Yukarı B A. An Abattoir Survey of Gastro-Intestinal Nematodes in Sheep in the Burdur Region, Turkey. Turk J Vet Anim Sci 2005;29:1195201.

18. Sevimli F. Checklist of small ruminant gastrointestinal nematodes and their geographical distribution in Turkey. Turk J Vet Anim Sci 2013;37:369-79.

19. Kurtpınar H. Erzurum, Kars ve Ağrı vilayetleri sığır, koyun ve keçilerinin yaz aylarına mahsus parazitleri ve bunların doğurdukları hastalıklar. Türk Vet Hekim Dern Derg 1956;26:3226-32.

20. Kurtpınar H. Erzurum, Kars ve Ağr. vilayetleri sığır, koyun ve keçilerinin yaz aylarına mahsus parazitleri ve bunların doğurdukları hastalıklar. Türk Vet Hekim Dern Derg 1957;27:3320-5.

21. Vural A, Doğru C, Onar E, Özkoç Ü. Erzurum bölgesi kuzularında paraziter fona tesbiti ve parazitlerin et verimine olan etkileri. Pendik Vet Mikrob Enst Derg 1980;12:27-47.

22. TUIK, 2018, Available from: URL: https://biruni.tuik.gov.tr/ hayvancilikapp/hayvancilik.zul.

23. Maff. Fisheries and Food. Reference Book. In: H M S O editors. Manual of Veterinary Parasitological Laboratory Techniques. London; 1986. 5pp.

24. Idris A, Moors E, Sohnrey B, Gaul, M. Gastrointestinal nematode infections in German sheep. Parasitol Res 2012;110:1453-9.

25. Pelledry L P. Coccidia and Coccidiosis. Parey, Berlin, 2. Auflage, 1974, 723 761.

26. Soulsby E J L. Helminths, arthropods and protozoa of domesticated animals. 6rd ed. Bailliere; 1986

27. Khan M N, Rehman T, Iqbal Z, Sajid M S, Ahmad M, Riaz M. Prevalence and Associated Risk Factors of Eimeria in Sheep of Punjab, Pakistan", World Acad Sci Eng Technol 2011;80:1329-34.

28. Chartier C. Paraud C. Coccidiosis due to Eimeria in sheep and goats, a review. Small Ruminant Res 2012;103:84-92.

29. Yakhchali M, Golami E. Eimeria infection (Coccidia: Eimeriidae) in sheep of different age groups in Sanandaj city, Iran. Veterinarski Arhiv 2008;78:57-64.

30. Çaya H. Adana ili Mezbahalarında Kesilen Küçük Ruminantlarda Karaciğer Helmint Enfeksiyonlarının şiddeti ve Yayılışı. AVKAE Dergisi 2012;2:1-17. 
31. Değer M S, Biçek K, Karakuş A. Prevalence of Dicrocoelium dentriticum in sheep and goats slaughtered in Van region (Van municipality slaughterhouse). Van Vet J 2017;28:21-4.

32. Aydın A. Hakkari Belediye Mezbahasında Kesilen Hayvanlarda Anolocephalidae Türlerinin Yayllışı. YYU Vet Fak Derg 2013;24:5-8.

33. Yıldırım A, İça A. Kayseri Yöresinde Koyunlarda Akciğer Kıl Kurdu Enfeksiyonlarının Prevalansı. Erciyes Üniv Vet Fak Derg 2015;2:73-8.

34. Singh R, Bal M S, Singla L D, Kaur P. Detection of anthelmintic resistance in sheep and goat against fenbendazole by faecal egg count reduction test. J Parasit Dis 2017;41:463-6.

35. Bansal D K, Agrawal V, Haque M. A slaughter house study on prevalence of gastrointestinal helminths among small ruminants at Mhow, Indore. J Parasit Dis 2015;39:773-6.
36. Khajuria J K, Katoch R, Yadav A, Godara R, Gupta S K, Singh A. Seasonal prevalence of gastrointestinal helminths in sheep and goats of middle agro-climatic zone of Jammu province. J Parasit Dis 2013;37:21-5.

37. Kantzoura V, Kouam M K, Theodoropoulo, H, Feidas H, Theodoropoulos G. Prevalence and Risk Factors of Gastrointestinal Parasitic Infections in Small Ruminants in the Greek Temperate Mediterranean Environment", Open Vet J (OJVM) 2012;2:25-33.

38. Merlin A, Chauvin A, Madouasse A, Froger S, Bareille N, Chartier C. Explaining variability in first grazing season heifer growth combining individually measured parasitological and clinical indicators with exposure to gastrointestinal nematode infection based on grazing management practice. Vet Parasitol 2016;225:61-9.

39. Yasmin C, Otoi T, Setiadi M A, Karja N W K. Maturation and fertilisation of sheep oocytes cultured in serum-free medium containing silk protein sericin. Acta Vet Hung 2015;63:110-7. 